\title{
Strategic Planning for System and Information Technology Using Anita Cassidy in PT. XYZ
}

\author{
Ni Luh Septiana Dharmayanti ${ }^{1}$ and Erma Suryani ${ }^{1}$
}

\begin{abstract}
The management system has been one of the essential components of information technology that uses technology to support operations and management. PT XYZ has 11 departments namely Marketing, Purchasing, Human Resource, Finance, General Affair, Engineering, Warehouse, Meat Processing, Bakery, $R$ \& D, Quality Control, and Cafe divisions. The number of employees of the entire divisions is approximately \pm 800 people. Applications has been used in operating the main business activity at PT XYZ on daily basis. However, the applications are still based on each division which will cause the business process to be out of control and the data disintegration in each division. It can be seen as a disadvantage to the product processing as the operation takes longer; hence, it consequently requires higher production costs. Moreover, PT XYZ still uses 3 of the 7 applications that have been developed, while it's also contributed by having limited number of staff who are able to operate desktop or web-based applications. In view of the above, this study aims to develop a suitable information system strategic plan for PT XYZ. The analysis was conducted by using Anita Cassidy's Strategic Planning, wherein the planning starts from upstream to downstream of the company's business process. Anita Casidy's method consist of 4 (four) stages including visioning, analysis, direction, recommendation. The results obtained were IS strategy, IT strategy and IT management. Based on the results, it revealed that, at the visioning stage, PT. XYZ is located in quadrant I, in which quadrant 1 supports aggressive strategies. The strategy that must be determined in this condition is supporting aggressive growth policy. In the analysis, the IS trends used were device mesh, information of everything, advanced machine learning, adaptive security architecture, advanced system architecture, mesh app and service architecture. It was found 25 ITS solutions in the direction stage. For the recommendation stage, there were 4 classifications of costs: resource costs of $R$ p. 685,286,896, hardware costs projected at Rp. 18,400,000, license fees of Rp. 304,737,080, and miscellaneous fees to be Rp. $192,240,897$.
\end{abstract}

Keywords-Strategic Planning, Annita Cassidy, PT. XYZ, IT Strategy.

\section{INTRODUCTION}

Nowadays, management system has been discerned as one of the important components of information technology that uses technology to support operations and management. In a broad sense, the term information system that is often used refers to interactions between individuals,

\footnotetext{
${ }^{1} \mathrm{Ni}$ Luh Septiana Dharmayanti and Erma Suryani are with Departement of Business and Management Technology, Institut Teknologi Sepuluh Nopember, Surabaya, Indonesia. E- mail: erma@is.its.ac.id.
}

algorithmic processes, data, and technology. In this case, the term is not only associated with the use of information and communication technology (ICT) organizations, but also with the ways in which people interact with technology [1].

PT XYZ is a company engaged in the food industry, fast food (frozen food), spices and sauces production. It is located at Jl. Lingkar Timur Blok B No 1-6 Buduran, Sidoarjo. The company was established on December 9, 1989 and manages 11 divisions. The number of employees of the entire divisions is approximately \pm 800 people. PT. $\mathrm{XYZ}$ has a vision to be the leading distribution network of frozen products and be able to compete in the national and international markets as it also pays attention towards product quality and the best service for its consumers. It is deemed as the core activity of the company since the input and process of making products to the marketing and sales of the products that generate corporate income are in the main activities. The core business at PT. XYZ has utilized several applications on a daily basis; however, the application is still based on each field. This has caused the business process to be uncontrolled as the data in each division is not integrated. This will potentially have a negative impact on the company, for instance the production takes longer to complete that it requires higher production costs. In consequence, higher production costs will affect the high selling price of the products [2]. It has become very clear that high-quality products have a prominent advantage in the market as the market share can increase or decrease due to quality issues. Therefore, quality is considered as a competitive priority [3].

The next step in maintaining product quality is by controlling production, in terms of quality control, quality assurance and quality planning. Quality planning is a process whereby standard identification of quality that is relevant to a project will be carried out to reveal satisfaction from consumers [4]. Based on the observations of the researchers, there are problems considering only 3 of the 7 applications are routinely used, and the application failure rate is quite high. Furthermore, in terms of HR, PT $\mathrm{XYZ}$ still does not have competent staff to operate desktop or web-based applications. In view of above statements of problem, the business activity at $\mathrm{PT} \mathrm{XYZ}$ requires an Information Technology System (ITS) plan. Strategic planning will be conducted in the present study by using the method of Anita Cassidy. This approach is deemed to 
be suitable for companies with the aim to develop their business processes.

\section{LITERATUR REVIEW}

\section{A. ITS Strategic Planning}

Strategic planning is a global level of thinking about organizational information systems that are integrated with the entire organization which must be coherent, consistent and directional. Coherent is defined as it achieves mutual understanding for both sides, namely organization and business while consistent is interpreted as the need to be built in order to fit together. Directional means directing changes into common goals. Several benefits of information system strategic planning are as follows [5]:

1. Establish more effective management on important company assets;

2. Improve relations and communication in business organizations and IS

3. Align the objectives and priorities of IS and business.

4. Identify opportunities for the use of technology for competitive advantages and to add business value.

5. Plan the process flow and information flow.

6. Allocate resources effectively and efficiently.

7. Reduce effort and costs needed.

ITS strategic planning is also able to elaborate tools, techniques, and frameworks for management to align the ITS strategy with business strategy, and to seek new opportunities through the implementation of innovative technologies [6]. Several characteristics of ITS strategic planning include the existence of a primary mission, namely strategic or competitive advantage and its relation to business strategy; referrals from executives or senior management and users; and the main approach in the form of user innovation and a combination of bottom up development and top down analysis [7]. Methodology and Stages of Information Systems Strategic Planning.

In conducting information system strategic planning, there are several methodologies that can be employed, namely:

\section{1) Anita Cassidy's Method}

\section{a. Visioning}

This stage explains about building and starting a planning project. Finalizing and communicating the goals are the forms of strategic planning efforts, as well as outlining what management expects to achieve the efforts.

b. Analysis

In the second stage, the overall analysis is executed objectively. In this case, it is usually conducted to provide information in regards to the situation of information systems to executive management.

\section{c. Direction}

In this phase, it describes the mission and vision that is tailored to the business situation and as a basis for strategic formulation and determining the direction of information systems in the future.

d. Recommendation

In this stage, documenting the project by creating a road map in detail is carried out to describe an action plan for the next few years, including summarizing the costs, time and resources needed. The steps taken are road map, business case, and communication.

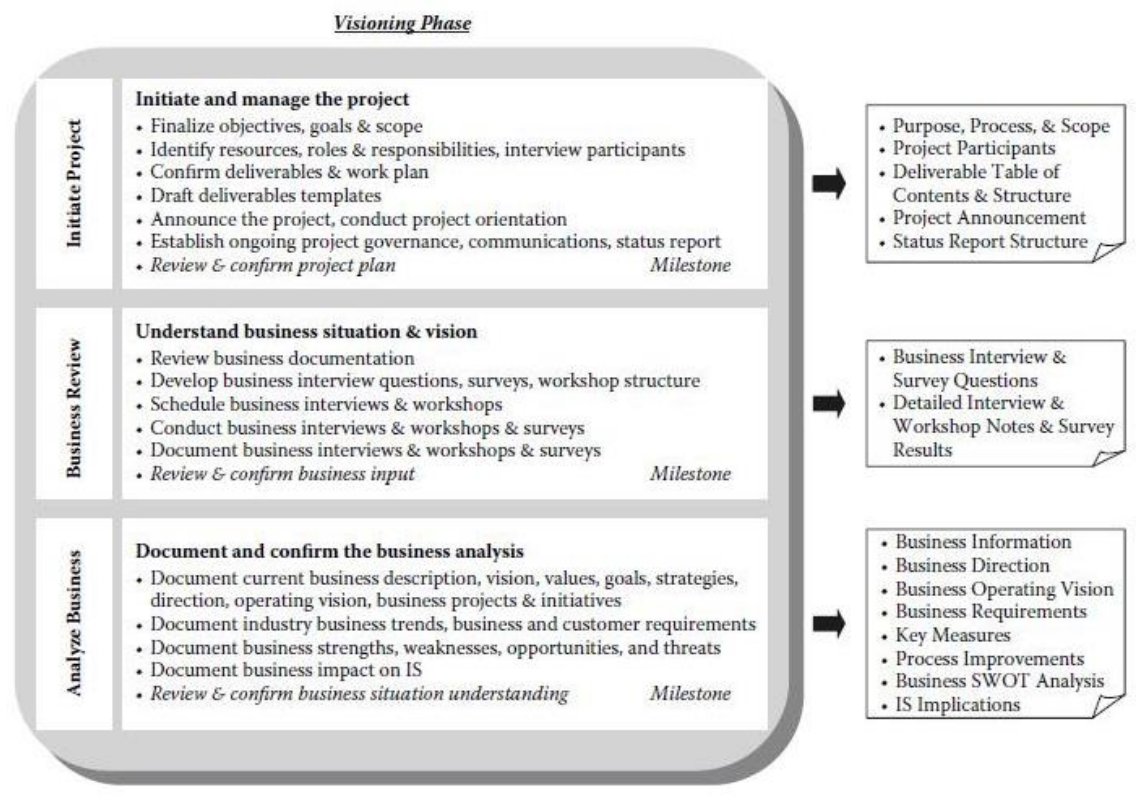

Figure 1. Visioning Phase 
IPTEK Journal of Proceedings Series No. (5) (2019), ISSN (2354-6026)

The $1^{\text {st }}$ International Conference on Business and Management of Technology (IConBMT)

August 3rd 2019, Institut Teknologi Sepuluh Nopember, Surabaya, Indonesia

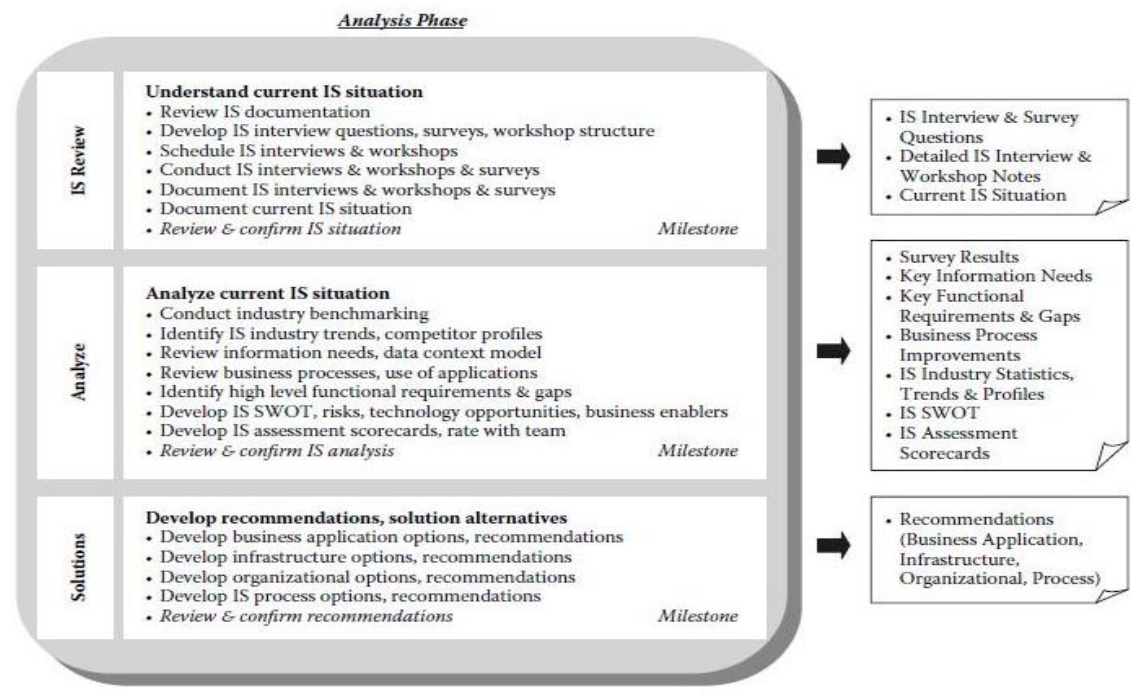

Figure 2. Analysis Phase.

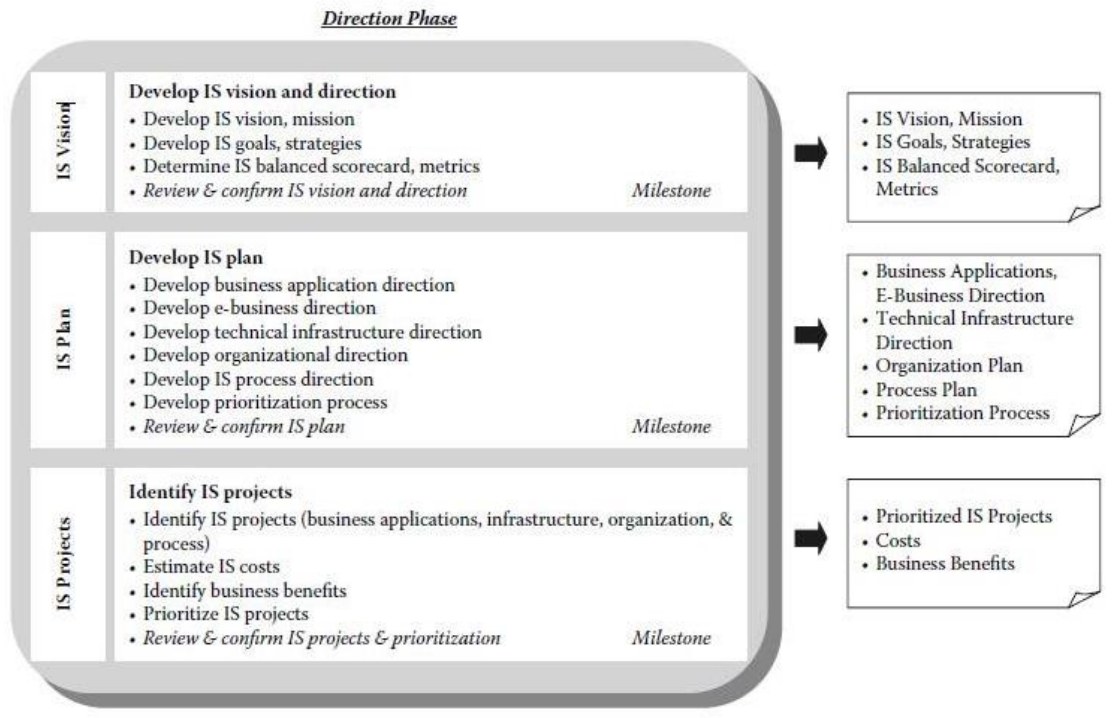

Figure 3. Direction Phase.

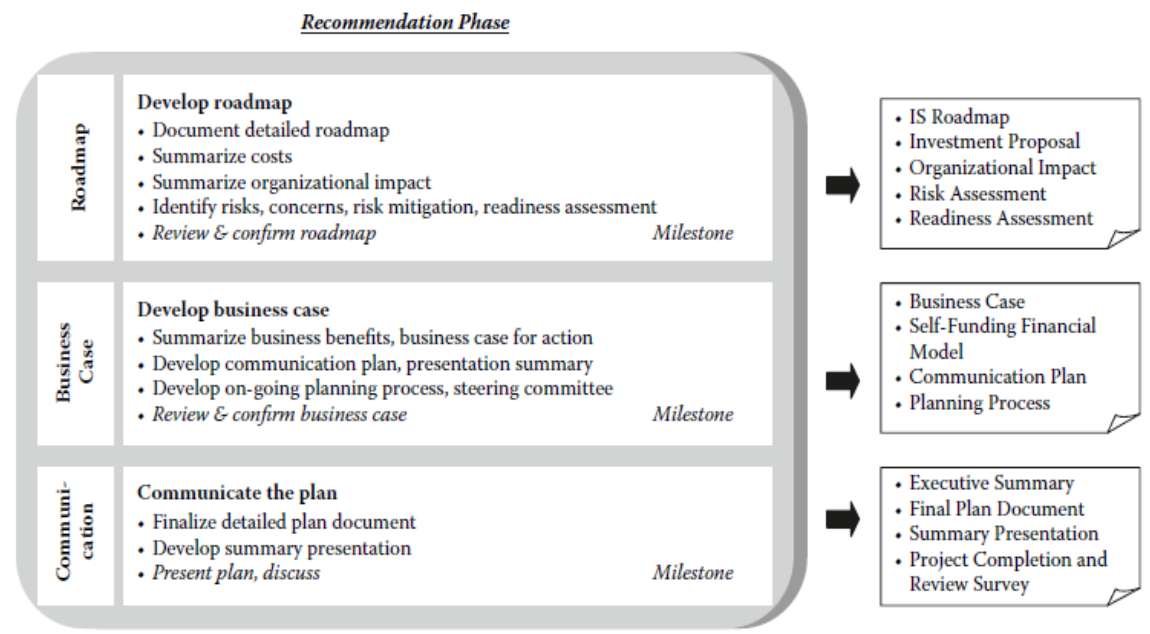

Figure 4. Recommendation Phase 
Visioning Phase

- Initiate and manage the project

- Understand business situation and vision

- Document and confirm the business analysis

\section{Analysis Phase}

- Understand current IS situation

- Analyze current IS situation

- Develop recommendations, solution alternatives
Direction Phase

- Develop IS vision and direction

- Develop IS plan

- Identify IS projects

Figure 5. Stages of Anita Cassidy's Strategic Planning

\section{2) Ward \& Peppard's Method}

The Ward \& Peppard planning model starts from the condition of investment in Information Technology (IT) in the past that is less useful for the company's business goals and captures business opportunities, as well as the use of Information Technology (IT) that can be used to improve a company's competitive advantage. There are 2 stages of the method used, namely the stages of input and output [6].

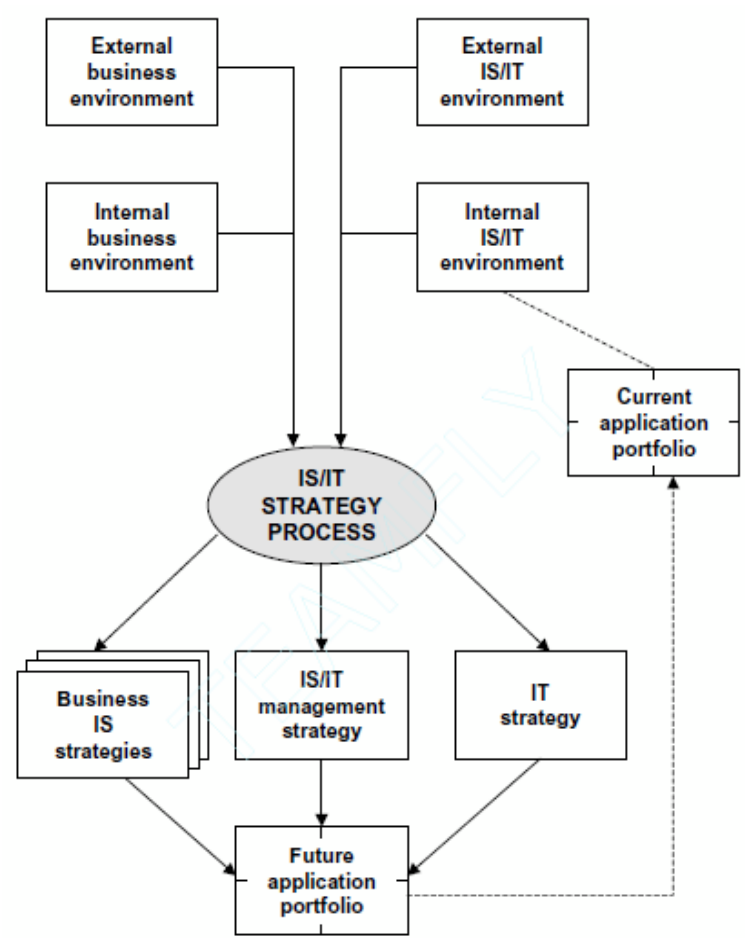

Figure 6. Ward \& Peppard's ITS Strategic Planning Methodology.

\section{B. Comparison of Ward \& Peppard's Methods and Anita Cassidy's Phases}

Based on the analysis of the activity sequence of both methods, there are similarities in terms of the process. All of these activities are compiled, assembled and sorted according to the UK Government CCTA and compared to the John Ward version. This is carried out by using input parameters required in the process stage and the output produced by the device used and the process itself [8].
Based on the results of comparisons conducted and aligning with the research's objective, Anita Cassidy methods are utilized in this study, taking into account several things as the following:

1. The phases and processes proposed by Anita Cassidy are easy to understand and have a clear and complete planning flow; hence, it will ease the analysis.

2. The method accommodates several stages of analysis such as SWOT, Value Chain Analysis, Five Force and Mc Farlan Potfolio.

\section{Methodology}

\section{A. Initial Phase}

In this initial stage, there are 2 steps that must be implemented, specificly conducting literature studies and collecting data related to ITS strategic planning at PT XYZ.

\section{B. Development Phase}

The steps taken after carrying out the initial stage are conducting the development stage. It consists of 4 stages, including the stage of visioning, analysis, direction and recommendation.

1) Visioning Phase

In this phase, there are 3 stages that must be carried out which are initiating project, business review and business analysis.

2) Analysis Phase

In the analysis phase, there are 3 stages that must be implemented: IS review, analysis and solution.

3) Direction Phase

There are 3 required steps to complete, namely IS vision, IS plan, and IS Project.

\section{4) Recommendation Phase}

This stage is aimed at documenting a strategic plan to make a detailed roadmap to describe an action plan for the next few years, such as summarizing the costs, time and resources needed.

\section{Last Phase}

In the final stage, an STI planning that has been validated by the company and the developer will be further arranged. 
The $1^{\text {st }}$ International Conference on Business and Management of Technology (IConBMT)

August 3rd 2019, Institut Teknologi Sepuluh Nopember, Surabaya, Indonesia

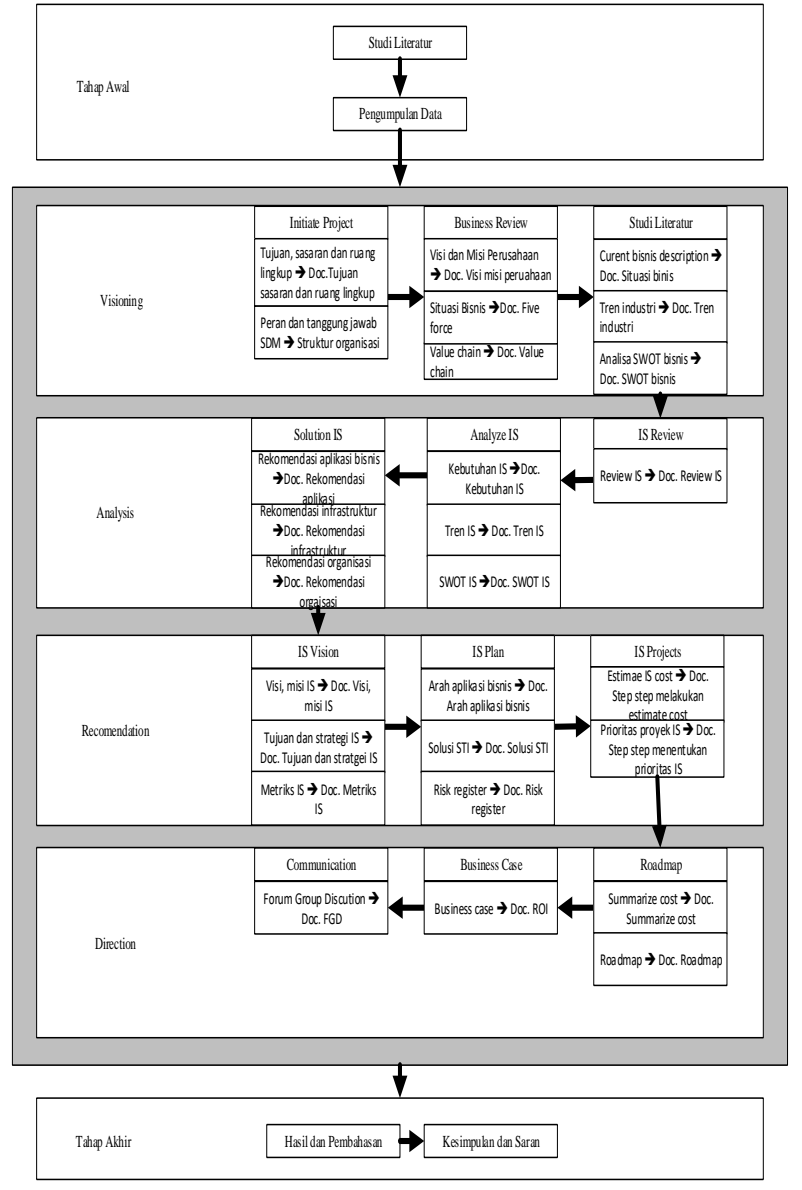

Figure 7. The Initial Phase of ITS Planning.

\section{RESUlT AND DisCUSSION}

\section{A. Visioning}

In the visioning phase, there are 3 processes that must be done, namely initiate project, business review and analyze business.

\section{1) Initiate Project}

a. Identification of Company Objectives, Target and Scope

- Identification of Company Objectives

PT XYZ is one of the companies engaged in the food industry that produces frozen food, cooking spices and sauces. This company has a goal to be "the leading distribution network of frozen products and be able to compete in the national and international markets as it also pays attention towards product quality and the best service for its consumers.

- Identification of Company Target

The primary target of PT XYZ in selling its products are large retail companies such as Giant, Hypermart, Hero, Carrefour, and Lotte Mart.

- Identification of Company Scope

PT XYZ has several products to be marketed to consumers, for instance processed frozen products such as Minipao, Bakpao, Siomay, Scalop, Sauces and spices.

\section{2) Business Review}

In the business review phase, there are 4 stages conducted which sre vision and mission analysis, business situation according to Five Force, buyer bargaining power, supplier bargaining power, and similar company competitors. The results are as follows:

TABLE 1.

RESUltS OF FIVE FORCE ANALYSIS OF PT. XYZ

\begin{tabular}{|c|c|c|}
\hline Factor & Problems & Solutions \\
\hline $\begin{array}{l}\text { Buyer } \\
\text { bargaining } \\
\text { power }\end{array}$ & $\begin{array}{l}\text { The number of other large } \\
\text { companies that have similar } \\
\text { products is very possible for } \\
\text { buyers to switch to using } \\
\text { other products. }\end{array}$ & $\begin{array}{l}\text { Making varied products } \\
\text { and implementing the } \\
\text { USP system }\end{array}$ \\
\hline $\begin{array}{l}\text { Supplier } \\
\text { bargaining } \\
\text { power }\end{array}$ & $\begin{array}{l}\text { Less suppliers of production } \\
\text { materials that have the best } \\
\text { quality for making high- } \\
\text { quality frozen products }\end{array}$ & \\
\hline $\begin{array}{l}\text { Competitors } \\
\text { of similar } \\
\text { companies }\end{array}$ & $\begin{array}{l}\text { The large number of large } \\
\text { companies that have several } \\
\text { Bernardi products has caused } \\
\text { intense competition }\end{array}$ & $\begin{array}{l}\text { Always maintain the } \\
\text { quality and quality of } \\
\text { frozen products } \\
\text { produced by the } \\
\text { company. }\end{array}$ \\
\hline
\end{tabular}

b. Value Chain

This Value Chain is used to discover all the business activities that exist in the company. The company's business activities can be divided into two categories, namely the main business activities and supporting business activities. The value chain at PT. XYZ can be seen below:

- The purchasing department has the task of purchasing raw materials for eggs, chicken, beef, vegetables, flour and others to the supplier. The output generated by this section is a list of raw materials that have been purchased which will later be used by the meat and bakery production department and the warehouse for storage.

- The warehouse section is responsible for the entry of raw materials and finished products and the release of raw materials and finished goods. The output that is produced is the report of the entry and exit of raw materials and the entry and exit of finished goods which will later be used as sales and meat and bakery production divisions.

- Meat and bakery products divisions are processing raw materials into finished goods. The output that is generated is the product report that has been produced and will later be used by the sales department.

- The R\&D division deals with product innovation and market analysis of what products have high sales. The output that is produced is a product with new innovations which will be liked by the community.

- The quality department will be tasked with maintaining not only the quality of the products produced but also the quality of the raw materials used. The output of raw material produced is in the form of the report on the quality of the materials used and for the products produced. It will be a list of products that have met the 
quality standards set by the company. This data will be used by the warehouse and sales department.

\section{3) Analyze Business}

a. SWOT Analysis

Based on the results of the SWOT analysis, it was found that PT. XYZ is located in quadrant 1 where quadrant 1 supports aggressive strategies. This situation is a favorable situation because it has strengths and opportunities in market competition.

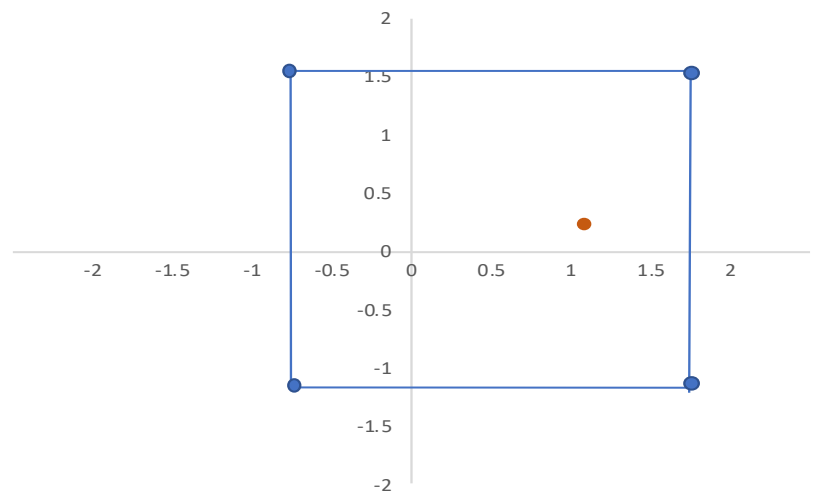

Figure 8 . The current position of the company's coordinates based on SWOT.

b. Impact of IS on the Company

Information system or commonly called IS has considerable potential in the future which causes the emergence of development every year in the field. This has a wide-ranging positive impact, one of which is business. In addition, the impact of IS can also be used by companies in marketing companies to introduce the products produced. This is carried out by creating a web company so that consumers can easily identify the company's products. This can facilitate the promotion of companies by doing digital marketing. Another benefit that can be utilized in business is that it simplifies the process of recording goods orders; hence, it will be recorded properly without any unregistered orders.

\section{B. Analysis}

1) SWOT IS

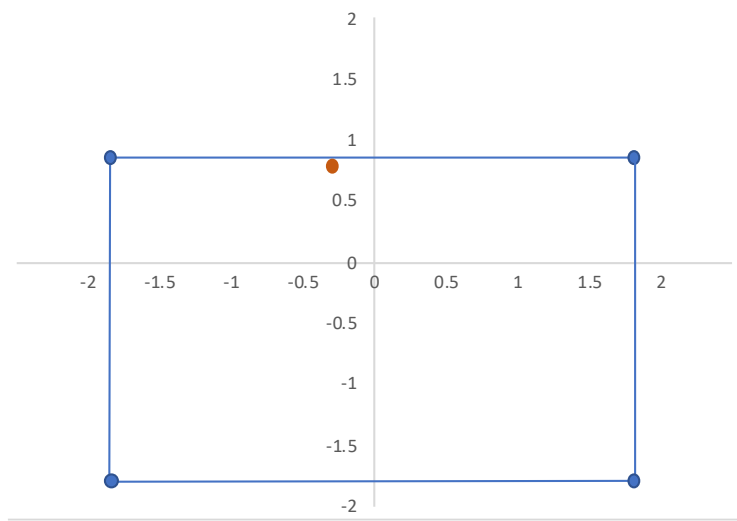

Figure 9. The current coordinates of the company based on SWOT IS.
Based on the results of the SWOT IS analysis, it was revealed that PT. XYZ is located in quadrant 2 where quadrant 2 supports the rationalization strategy. This situation is interpreted as in a fairly good condition. However, it experiences a number of severe challenges so that the company will experience difficulties in developing if it still uses the previous strategy.

2) Develop an IS Scorecard

The results obtained from the IS Scorecard at PT. XYZ run as follows:

TABLE 2 .

AVERAGE OF SCORECARD SUMMARY

\begin{tabular}{clc}
\hline \hline No & Assessment Aspect & Average \\
\hline 1 & Strategy & 3.4 \\
2 & People & 3.6 \\
3 & Process & 3.3 \\
4 & Business application & 3.3 \\
5 & Technical infrastructure & 2.6 \\
\hline \hline
\end{tabular}

\section{Direction}

1) IS Vision

To be the company that carries out development, provide services in the form of information and communication technologies on IT basis.

2) IS Mission

Building a web company, conducting company call center services, creating programs that make it easy for consumers to place orders online.

3) IS Objective

Expand the company's market share, facilitate ordering raw materials to vendors, and improve company performance.

4) IS Strategy

Creating a company website, promoting a company website, making a system for ordering raw materials to vendors, making SOPs in each division

\section{5) ITS Solution}

The ITS solution is an application design that has a specific function, where functions are taken according to the activities and needs of the company ITS.

\section{6) Upcoming Application Portfolio}

To obtain a portfolio of future applications, FGD among stakeholders is conducted with questions as in Table 4.

7) Business Strategy

At this stage, we will discuss the direction of the company in determining the ITS solution.

8) STI Architecture

Integration architecture is designed according to the ITS process. A square symbol indicates that the information system is related to business processes that are used daily whereas the circle symbol indicates the supporting information system. In the process of making ITS integrase architecture, interviews were conducted with IT Staff at PT. XYZ so that STI architecture can be well depicted. 
IPTEK Journal of Proceedings Series No. (5) (2019), ISSN (2354-6026)

The $1^{\text {st }}$ International Conference on Business and Management of Technology (IConBMT)

August 3rd 2019, Institut Teknologi Sepuluh Nopember, Surabaya, Indonesia

TABLE 3.

ITS SOLUTION IN PT. XYZ

\begin{tabular}{|c|c|}
\hline Activity & ITS Solution \\
\hline Purchase of raw materials & $\begin{array}{l}\text { 1. Purchasing IS } \\
\text { 2. Supplier GIS } \\
\text { 3. Manufacture IS } \\
\text { 4. Raw material inventory IS }\end{array}$ \\
\hline Quality control of raw materials & 1. Quality Control IS \\
\hline Production process according to standard & $\begin{array}{l}\text { 1. Production IS } \\
\text { 2. Information Technology Governance of production according to standards }\end{array}$ \\
\hline Quality control of products & $\begin{array}{l}\text { 1. Quality Control IS } \\
\text { 2. Process Control System } \\
\text { 3. Information Technology Governance of product quality }\end{array}$ \\
\hline Customer order & $\begin{array}{l}\text { 1. Transaction Processing System (TPS). } \\
\text { 2. CRM (Customer Relationship Management) }\end{array}$ \\
\hline Product development research & $\begin{array}{l}\text { 1. Selling IS } \\
\text { 2. DSS of products developed }\end{array}$ \\
\hline Factory shop development & $\begin{array}{l}\text { 1. Decision support systems (DSS) } \\
\text { 2. Strategic Information Systems }\end{array}$ \\
\hline Send products on time to customers & $\begin{array}{l}\text { 1. Strategic Information Systems } \\
\text { 2. DSS of Determination of the Shortest Route }\end{array}$ \\
\hline Delivery of goods with a certain total purchase & $\begin{array}{l}\text { 1. Distribution IS } \\
\text { 2. DSS of of Determination of the Shortest Route }\end{array}$ \\
\hline Obtain new customers and maintain old customers & $\begin{array}{l}\text { 1. Marketing IS } \\
\text { 2. CRM (Customer Relationship Management) }\end{array}$ \\
\hline Promotions and discounts for members & $\begin{array}{l}\text { 1. Marketing IS } \\
\text { 2. CRM (Customer Relationship Management) }\end{array}$ \\
\hline Build customer complaint service & $\begin{array}{l}\text { 1. Communication and Collaboration System } \\
\text { 2. CRM (Customer Relationship Management) }\end{array}$ \\
\hline Accounting and payroll & $\begin{array}{l}\text { 1. Accounting IS } \\
\text { 2. Payroll IS } \\
\text { 3. Transaction Processing System }\end{array}$ \\
\hline Taxation & $\begin{array}{l}\text { 1. Finance IS } \\
\text { 2. Taxation IS } \\
\text { 3. Accounting IS }\end{array}$ \\
\hline Hiring of new staff & $\begin{array}{l}\text { 1. HR IS } \\
\text { 2. Employee Recruitment System } \\
\text { 3. DSS }\end{array}$ \\
\hline Staff training & $\begin{array}{l}\text { 1. HR IS } \\
\text { 2. Employee Performance Assessment and Training System }\end{array}$ \\
\hline Establish good cooperation with suppliers & 1. E-Procurement \\
\hline
\end{tabular}

TABLE 4.

QUESTIONS OF UPCOMING APPLICATION PORTFOLIO

\begin{tabular}{ll}
\hline \hline No & \multicolumn{1}{c}{ Question } \\
\hline 1 & Does the ITS solution produce clear competitive advantages for the company? \\
2 & Can this ITS solution be used in achieving specific business goals? \\
3 & Can the ITS solution overcome the business losses associated with company competitors? \\
4 & Can the ITS solution avoid business risk that will become a major problem in the future? \\
5 & Can the ITS solution improve business productivity by reducing longterm costs? \\
6 & Can the ITS solution enable organization to meet emerging needs? \\
7 & Can the ITS solution provide benefits that are not yet known but make it possible to produce point a and b? \\
\hline \hline
\end{tabular}


The $1^{\text {st }}$ International Conference on Business and Management of Technology (IConBMT)

August 3rd 2019, Institut Teknologi Sepuluh Nopember, Surabaya, Indonesia

TABLE 5.

BUSINESS STRATEGY

\begin{tabular}{|c|c|}
\hline Business Strategy & IS Organization \\
\hline 1. Focusing on the production of goods with the variety of products that are launched & \multirow{4}{*}{ Each division has responsibilities for each job } \\
\hline 2. Research the needs and tastes of consumers in the future & \\
\hline 3. Has quality product standards & \\
\hline 4. Conduct market exploitation & \\
\hline Technology & IS Metrics \\
\hline 1. Staff must be able to control existing ITS & \multirow{2}{*}{ Following the ITS project work time } \\
\hline 2. Use of technology in the ordering of raw materials, production, quality control, RnD etc. & \\
\hline IS Strategy & IS Process \\
\hline 1. ITS helps business processes. & \multirow{2}{*}{ The uniqueness of ITS will affect the costs incurred. } \\
\hline 2. ITS can support the company's strategy. & \\
\hline 3. ITS can help secure data owned by the company. & \multirow[t]{3}{*}{ Develop information systems according to the stages. } \\
\hline 4. ITS can help companies to establish good relationships with vendors and customers. & \\
\hline 5. ITS can help to advertise and market the products owned by the company. & \\
\hline
\end{tabular}

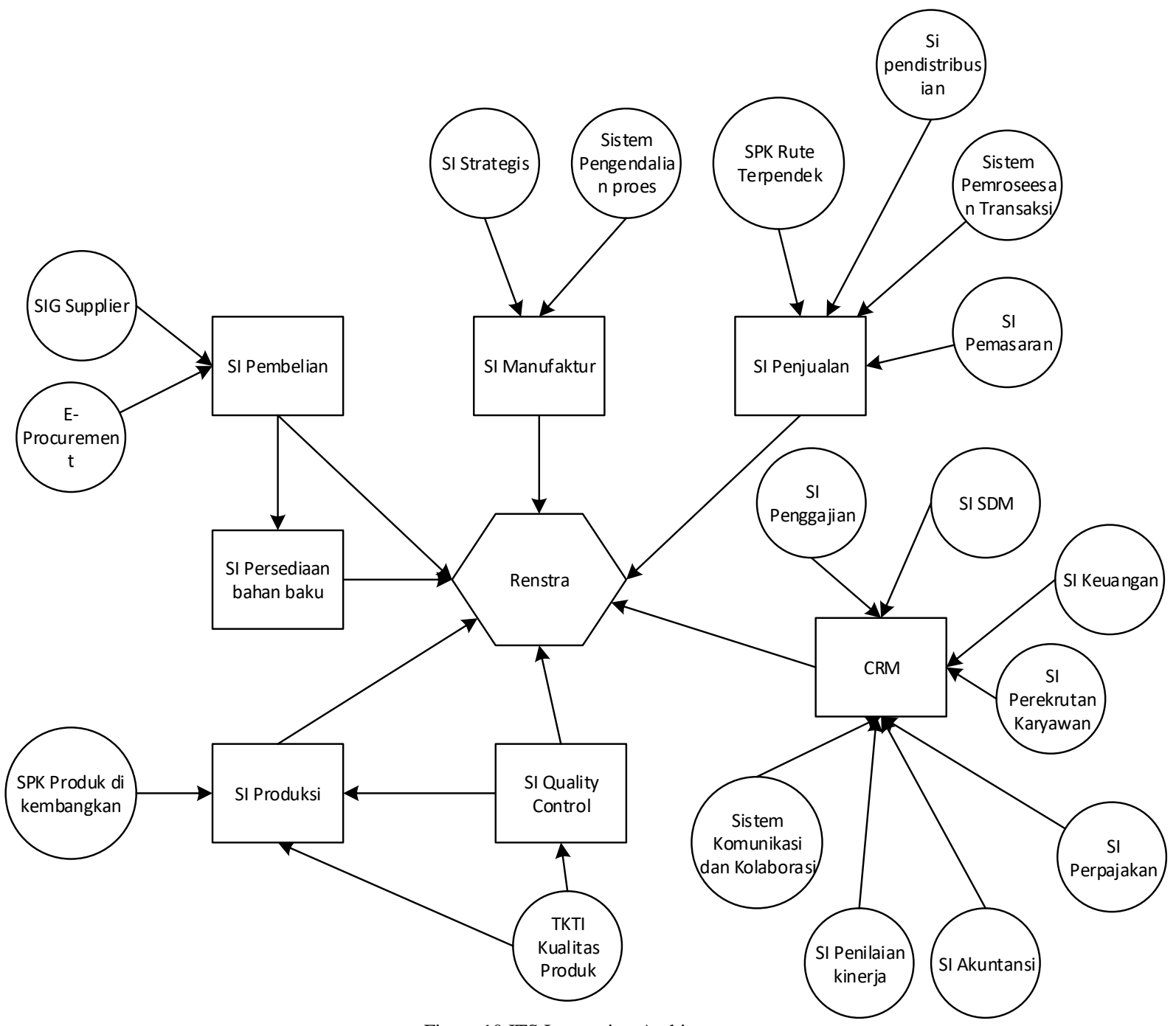

Figure.10 ITS Integration Architecture. 
The $1^{\text {st }}$ International Conference on Business and Management of Technology (IConBMT)

August 3rd 2019, Institut Teknologi Sepuluh Nopember, Surabaya, Indonesia

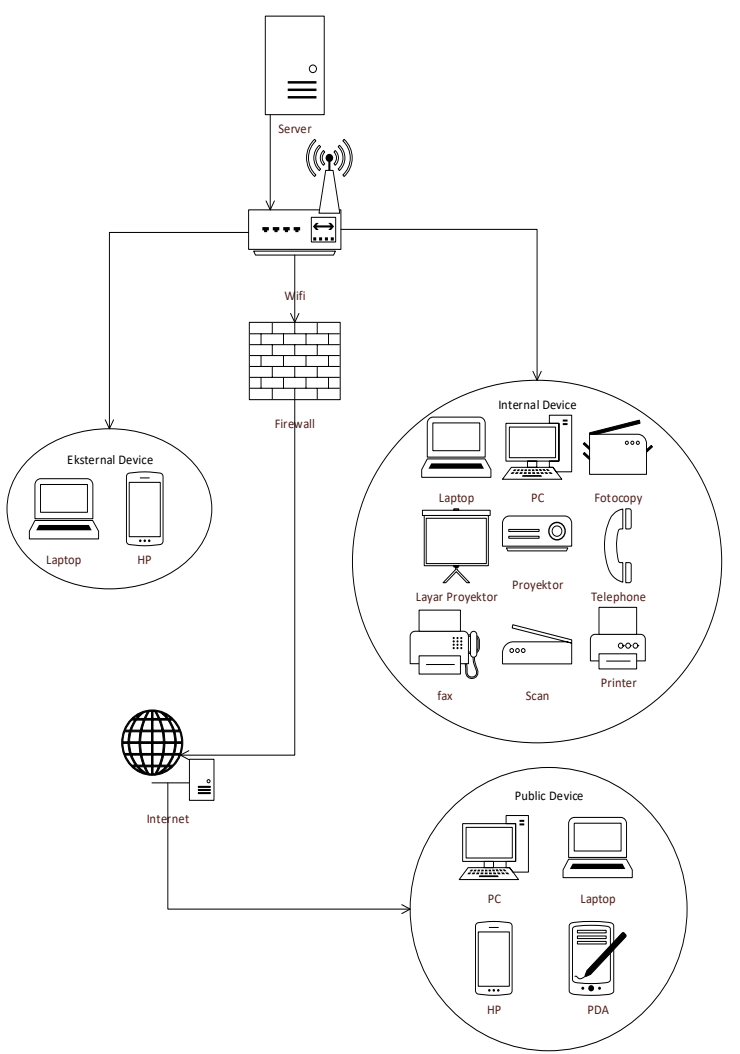

Figure 11. Technology Infrastructure Architecture.

9) Project IS Priority

In determining the priority of IS projects viewed from various aspects, the aspects seen are the company's dependence on IS projects which are then linked to the estimated business value, estimated time of implementation, project risk estimates, estimated implementation and maintenance costs. Afterwards, the project IS priority is confirmed.

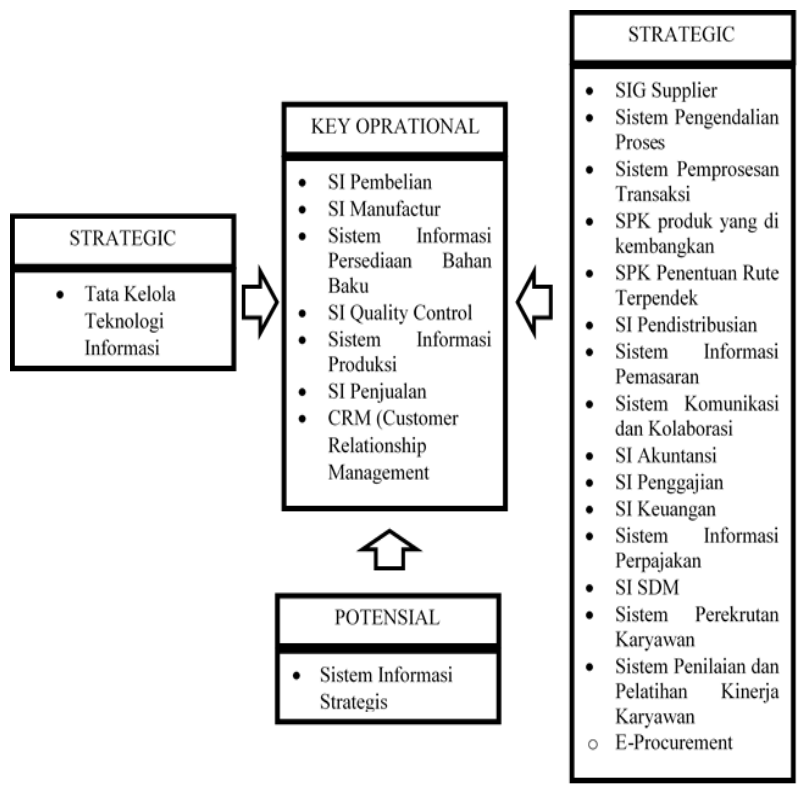

Figure 12. Project IS Mapping Priority.
TABLE 6.

PROJECT IS

\begin{tabular}{|c|c|c|c|}
\hline Strategic & Priority & Support & Priority \\
\hline \multirow{16}{*}{$\begin{array}{l}\text { Information } \\
\text { Technology } \\
\text { Governance of } \\
\text { production }\end{array}$} & \multirow{16}{*}{ I } & Supplier SIG & I \\
\hline & & Process Control System & III \\
\hline & & $\begin{array}{l}\text { Transaction Processing } \\
\text { System }\end{array}$ & III \\
\hline & & DSS of products developed & II \\
\hline & & $\begin{array}{l}\text { DSS of of Determination } \\
\text { of the Shortest Route }\end{array}$ & III \\
\hline & & Distribution IS & III \\
\hline & & Marketing IS & III \\
\hline & & $\begin{array}{l}\text { Communication and } \\
\text { Collaboration System }\end{array}$ & III \\
\hline & & Accounting IS & IV \\
\hline & & Payroll IS & IV \\
\hline & & Finance IS & IV \\
\hline & & Taxation IS & III \\
\hline & & SI SDM & IV \\
\hline & & HR IS & IV \\
\hline & & $\begin{array}{l}\text { Employee Performance } \\
\text { Assessment and Training } \\
\text { System }\end{array}$ & IV \\
\hline & & E-Procurement & IV \\
\hline Key Operational & Priority & Support & Priority \\
\hline Purchasing IS & I & \multirow{7}{*}{$\begin{array}{l}\text { Strategic Information } \\
\text { Systems }\end{array}$} & \multirow{7}{*}{ III } \\
\hline Manufacture IS & II & & \\
\hline $\begin{array}{l}\text { Raw material } \\
\text { inventory IS }\end{array}$ & I & & \\
\hline Quality Control IS & II & & \\
\hline Production IS & III & & \\
\hline Selling IS & II & & \\
\hline $\begin{array}{l}\text { CRM (Customer } \\
\text { Relationship } \\
\text { Management) }\end{array}$ & II & & \\
\hline
\end{tabular}

\section{Recommendation}

In the recommendation phase, detailed road map documents and steps to reach the direction stage will be carried out. The road map ensures that the plan will be realized. In this stage contains four cost, they are resource cost, hardware cost, lisece cost, miscellaneous cost. For the details will be describe in Table 7 .

TABLE 7.

TOTAL FINANCING

\begin{tabular}{clc}
\hline \hline No & \multicolumn{1}{c}{ Cost Clarification } & Total Strategy Cost \\
\hline 1 & Resource costs & Rp. 685.286 .896 \\
2 & Hardware costs & Rp. 18.400 .000 \\
3 & License Fee & Rp. 304.737 .080 \\
4 & Miscellaneous fees & Rp. 192.240.897 \\
\hline \hline
\end{tabular}




\section{CONCLUSION}

PT XYZ is a company engaged in the food industry, fast food (frozen food), spices and sauces production. It is located at Jl. Lingkar Timur Blok B No 1-6 Buduran, Sidoarjo. The company was established on December 9, 1989 and manages 11 divisions namely Marketing, Purchasing, Human Resource, Finance, General Affair, Engineering, Warehouse, Meat Processing, Bakery, R \& D, Quality Control, and Cafe divisions. The number of employees of the entire divisions is approximately \pm 800 people. PT. XYZ has a vision to be the leading distribution network of frozen products and be able to compete in the national and international markets as it also pays attention towards product quality and the best service for its consumers.

Based on the results of ITS Anita Cassidy strategic analysis, there are 4 stages of analysis, namely visioning, analysis, direction, recommendations and obtained in the form of IS strategy, IT strategy and IT management.

At the Visioning stage, it was found that PT. XYZ is located in quadrant 1 where quadrant 1 supports aggressive strategies. This situation is a favorable situation because it has strengths and opportunities in market competition.

In the analysis phase, it was revealed that PT. XYZ is located in quadrant 2 where quadrant 2 supports the rationalization strategy. This situation is interpreted as in a fairly good condition. However, it experiences a number of severe challenges so that the company will experience difficulties in developing if it still uses the previous strategy.

It was found 25 ITS solutions in the direction stage which will be used to facilitate the business activities. For the recommendation stage, there were 4 classifications of costs: resource costs of Rp. 685,286,896, hardware costs projected at Rp. 18,400,000, license fees of Rp. 304,737,080, and miscellaneous fees to be Rp. 192,240,897.

For the IS strategy, it is required to improve the vendor booking system by utilizing the developed ITS, create customer complaint services, create ITS data security systems, improve the system on company HR including the recruitment of new staff, creating job SOPs and updating the company's website. For the IT strategy, the results are implementing a management system to improve tools for network management, increasing clustering and SANs activities, reviewing the design and use of data centers to ensure efficient use, and using PDAs in their business processes. IT Management is to support the IS and IT strategy, which is managing $\mathrm{HR}$ management for all planning and conducting HR training.

\section{REFERENCES}

[1] R. McLeod, Sistem Informasi Manajemen. Jakarta, Indonesia: Prenhallindo, 1995.

[2] K. Sunarto, Pengantar Sosiologi . Jakarta: Lembaga Penerbit Fakultas Ekonomi, Universitas Indonesia, 2004.

[3] E. S. Buffa, Manajemen Operasi/Produksi Modern. Jakarta: Penerbit Binarupa Aksara, 1996.

[4] PMBOK, A Guide To The Project Management Body of Knowledge. Pennsylvania: Project Management Institute, 2013.

[5] A. Cassidy, A Practical Guide to Information System Strategic Planning, 2nd ed. Boca Raton, Florida: Auerbach Publication, 2006.

[6] J. Ward and J. Peppard, Strategic Planning for Information Systems, 3rd ed. Chichester, West Sussex, England: John Wiley \& Sons Inc, 2002.

[7] S. Pant and C. Hsu, "Strategic information systems planning: A review," in Information Resources Management Association International Conference, 1995.

[8] N. K. Denzin and Y. S. Lincoln, The Sage Handbook of Qualitative Research. Thousand Oaks, California: SAGE Publications, 2009. 